\title{
Green Tourism in Latin America
}

\section{Korstanje Maximiliano}

\author{
University of Palermo, Argentina
}

\begin{abstract}
This discussion centers on the limitations and opportunities of green tourism for Latin America. This reflects the past experience with CICATUR as well as the next guidelines towards a sustainable tourism. Basically, this situates as sometime else than a simple review of already-existent studies and literature. Rather it focuses on a critical discussion on the role of development in generating centre-periphery dependence. While the current problems of ecology seems to equal nations in the same level, no less true is that richer nations tend to impose their own discourse respecting to their right to contaminate further than pour nations. Doubtless, the problem of climate change is far from being solved and in this work we explain the reasons behind. As one of the largest ecological reservoirs of humankind, Latin America has much to say in this issue.
\end{abstract}

Keywords: Global Warming, Climate Change, green tourism, Latin America

\section{INTRODUCTION}

Green Tourism seems to be a buzzword often associated to derived forms of tourism as eco-tourism, sustainable tourism or even rural tourism. Most likely, one of the limitations scholars often face to deal with green-tourism is the lack of unified conceptual platform that encompasses many divergent fields and sub-segments (Ashworth, 1992; Hjalager, 2000; Sofield 2003). Beyond the rivalry and discussion to impose a shared meaning of green-tourism what is clear is that this sub segment emerged after Bruntland report through 80s decade. Legally known as "World Commission on Environment and Development" (WCED), this document was the first step to gather nations and governments in quest of a more sustainable world. Originally supported by United Nations, commission which was chaired by Gro Harlem Brundtland agreed that the world as we know can very well change to more inhospitable forms, if governments do nothing not only to reduce contamination, but planning the climate of consumption that leads towards local resources exhaustion. In this meeting, by first time, authorities referred to "sustainable development" to harmonize the rise of a new global order which was oriented to connect asymmetrical economies with the needs of protecting environment. Though the theory of development was widely criticized by many voices because of international business corporation as IMF or World Bank took advantage of the discourse of development to enhance their profits (Wheeller 1991; Esteva \& Prakash, 1998; McMichael 2016), no less true was that Bruntdland report was a touchstone to expand new programs which adjoined to tourism improved the condition of life of many rural communities worldwide (Roberts \& Hall, 2001; Timothy \& Sharpley, 2002; Hall 2004; Cole 2006; Comaroff \& Comaroff, 2009). Emanuel de Kadt (1979), in his classic book, Tourism: passport to development?, claimed for interdisciplinary research to understand in what study-cases, development created further problems than solution. In view of that, he acknowledges that those nations enrooted in a legacy of enslavement or systematic oppression were prone to adopt programs of development which do not reach a fairer wealth distribution while others nations which have been independent of European forces, successfully obtained interesting stage of well-being. Unlike for what Marxian writers preclude, for de Kadt, it is not tourism an mechanism used by a financial elite to exert further centre-periphery dependence, but only an instrument which can be a double-edged sword. Quite aside from this discussion, the paradigm of green-tourism centers on the preservation of soil, territory, or environment as the main aim to fulfil (McBoyle 1996), which can be crystalized in a program of incentives for those destinations that adopt sustainable policies, or even awards issued to promote a competition that prioritizes the rationality in pro environmental issues (Font \& Tribe, 2001).

As this backdrop, in this review-essay we explore critically the ebbs and flows of specialized literature in green-tourism as well as the study-case of Latin American destinations. It is not accident 
that green tourism was a term initially coined at northern hemisphere, only to be applied in "the global south". This means that though southern nations as New Zealand and Australia did devote considerable resources for expanding the studies in green-tourism issues, the international demand is regulated by main economies as France, England, US, and China. To put this slightly in other terms, while northern countries (which are associated to tourist-delivering societies) focus on economic development as the precondition towards progress, global southern cultures (which are touristreceiving societies) are more interested in promoting green-tourism programs instead. This piece does not represent a review of whole literature simply because of time and space, but it limits only to the "reception of green tourism" in Latin Americans. As R. Bandyopadhyay (2012) puts it, tough colonialism diluted over recent centuries, there was a strange sentiment of nostalgia where concepts which are forged in Europe are enthralled as superior than other voices, theories, paradigms or beliefs, coming from peripheral cultures. To what extent, green-tourism is conducive to a state of dependency which symbolically legitimizes policies of exploitation can be validated or discussed according to their success or failures in the field. The effects of green tourism in rural economies is one of the main points of entry in this discussion, scholarship would take seriously into consideration.

\section{Preliminary Discussion}

Undoubtedly, Jost Krippendorf, though unrecognized in Anglo-World, has played a pivotal role in constructing the necessary epistemological borders between tourism and ecology. He innovatively ignited a new tradition in tourism studies which paid heed to the advance of industrialization as an alienatory force which is based on the conditions of exploitation. Krippendorf sees tourism as an inherent part of leisure which was an universal projection of the needs of relax. At the time, the condition of exploitations over workforce increased in the evolution of capitalism, tourism would play a crucial role legitimizing the status quo. However, quite aside from Marxism, he did not feel the exploitation resulted from the monopoly of means of production but from the cultural values that ushered us into the "big fish eats the small fish" doctrine. Therefore, the social marketing, adapted to new more humanist values, can do of this world a better place. Oriented to understand what he dubbed as the tourist-consciousness, Krippendorf defined tourism as an universal force which is codetermined by the quest of newness to articulate a psychological all-encompassing theory where the self needs from evasion to revitalize its frustrated personality. To what extent, tourism contaminates environment or can be helpful in protecting ecology depends on the means of production each society develops. While hyper-consumerist societies are prone to commoditize landscapes, a more sustainable society is possible if Occident changes rapidly its economic matrix. Of course, the incipient problems in Ozone-layer leads Krippendorf to exerts a radical criticism on the ecological issues. He considers that we have to work hard to revere the contamination as well as the problems of pollution in the atmosphere. Unlike what social imaginary precluded, he adheres to the thesis the responsibilities for contamination should not be limited to states alone, because practices are shared and voluntarily accepted by all members of society. This is the reason behind citizens should cooperate to change the cultural matrix that mould individual behaviour. In this discussion, social marketing would be great if policy-makers are moved to change the current patterns of consumption for more sustainable ways (Krippendorf, 1982; 1986; 1987a; 1987b). Recently, the concerns for the rise of climate change inspired the proliferation of interesting literature though the legacy of Krippendorf was not correctly appreciated. In their book, Tourism and Climate Change, three authorative scholars, D. Scott, M. Hall and S Gossling (2012) write that specialists should not ignore climate change causes disasters, and serious economic losses worldwide. Based on the accuracy of technology to measure and anticipate the impacts of climate change, tourism would work to reverse high-carbon gases emission. The question whether tourism falls in a deeper paradox, because it may contribute to the acceleration of green-house gases, which threatens tourism, at some extent, tourism helps alleviating the emission of gasses globally. What this book left behind is that that social behaviour results from basic cultural values. As the British anthropologist Tim Ingold put it, the inconsistencies of sustainability and development are paradoxically based on the same system of beliefs (Ingold, 2000). The concept of sustainability and eco-protection imagine spaces as the reservoirs without human presence. This type of preservation is signalled by the logic of submission, measurement, and control of capitalism. Historically, not only sustainability but also developments were rooted in the capitalist ethos in a subtle way, in that they encouraged the idea of intervention which has been widely criticized by scholars of markets and the business world. 
Capitalism, as more than an economic project, is embedded in the lifestyle of Western societies by altering many of its primary institutions. The first ideological fallacy imposed by capitalism was the assurance that the world should be divided between humans and non-humans. The second was the division between work and leisure. Unlike hunters and gatherers who see the world from a relational perspective, modern cosmology understands territory from the "dwelling perspective".

For the relational perspective, humans and animals are united in the same cosmology reconciling the separation between man and his landscape. Hunters and gatherers take the food of animals to survive in order to meet their basic needs. Starting from the premise that nature gives humans everything they need, wealth accumulation should not be feasible in these economies. The concept of surplus is not valorised by the relational perspective. In contrast, the dwelling perspective conceives of space as something which can be filled by the human presence. In doing so, the man builds by controlling nature. The environment is portrayed as a dangerous place for humans who are pressed to develop adaptive techniques. Culture plays a vital role by providing humans with effective adaptations. This dualism, which was central to capitalism, inspired rapid innovations in technology, the division of labour, markets, science, and of course the tourism industry. Today, even the most radical ecofriendly supporters cannot reverse this trend. National parks and eco-reservoirs are built as shelters where the presence of humans is limited. This happens simply because the dwelling paradigm appeals to the rationalization of what is not human. The original separateness between humans and animals leads to policies to intervene for good or ill directly in the environment. This pervasive logic, which caused the climate change, still persists in the modern eco-protection paradigm.

The same can be applied to tourism. Ingold (2011) recognizes that the dichotomy between leisure and work was imported by capital owners in order for the workforce to fit their incomes in their pockets. Forging the myth that leisure liberates workers from oppression, the ideology of capitalism reserved the right to mark not only goods, but also workers. Their free time was occupied by the needs of consuming what they produced in their working time. In contrast, the hunter-gatherer tribes have developed a relational perspective where the animal serves as protector of humankind (Ingold, 2000).

Last but not least, the radical rupture of modern man with its environment is not new. Historians acknowledge that the change was introduced by modern capitalism and the industrial revolution a couple of centuries back. Not surprisingly, our medieval ancestors had not developed the technology to measure the effects of their own acts. A starting point for discussion could be how the West may mitigate the effects of its own ideology, oddly a system of beliefs that led us to a downright dilemma, the greed and the need to control the environment. Blind by our own ideology we are unable to change the trajectory of climate change, except by passing from dwelling to relational perspective (Korstanje \& George, 2012). In next section we will explore the roots and evolution of green tourism literature as well as its main problems and controversies.

\section{THE RoOTS OF GREEN TOURISM}

Originally, in their book Scott Lash \& John Urry (1993) confirmed that exchange of signs, which characterizes the modern economy resulted from the exhaustion of local resources. If classic tourism alluded to the massification of gaze, now it sets the pace to new forms where segmentation and the individualisation plays a crucial role in connecting globalization with consumption. Basically, environmental awareness emerged as an alternative to expand policies oriented to protection (Stabler \& Goodwall 1997). A Jones defines green tourism as intertwined to ecology in which case people are fostered to adopt rural activities in a sustainable way not only to give further benefits to local communities, but activists which are oriented to protect environment (Jones 1997). As this backdrop, Gibson, Dodds, Joppe \& Jamieson (2003) developed the concept of urban green tourism to show how a city may promote sustainable tourism generating a unique sense of experiences. Doubtless, the belief whether green tourism is associated to nature, not only should be reconsidered but also ecology should be embraced as a main value of next generation to make of this world a safer and better place to live. In this vein, Romeril (1989) argues that the adverse effects on environment makes imperative to think the nature of tourism within the logic of ethics. The pressure to adopt sustainable policies, which leads to eco-tourism will bring in further profits for investors and local stakeholders. Last but not least, it is tempting to say that green tourism is a term coined to denote sustainable practices in tourism fields, but the adoption of this term induced scholars to some misconceptions. Underpinned in the preposition that profits are the main vehicle to progress, practitioners and academicians lose the sight beyond the adoption of green ecological programs, tourism not only is far to be the agent of 
development social imaginary thinks, but sometimes humankind is imagined as an external entity separated from nature (Korstanje \& George 2015). In order to protect the non-removable resources the allegory of sustainability alludes to reduce the climate of mass-consumption which characterizes global capitalism. However, no less true is that in tourism fields, the paradigm was redefined only to protect the interests of investors and other stakeholders (Bramwell \& Lane 1993). Although tourism benefited communities in many ways, as Jafari puts it, some unexpected consequences may very well surface. The paradigm of sustainability was widely questioned by some critical studies as (Harrisson, 1996; Hall, 1991, Saarinen, 2006). Over recent years, the problem of climate change posed a great danger to tourism industry. To what extent tourism can change society or not, is a pending issue but what is important to discuss is that the dichotomy lies in the fact lay people understand the urgency to care the planet, but at the same time, they are doing nothing to change. British Senior Sociologist Anthony Giddens (1999) called this as "the paradox of Giddens", which consists in concerning of issues in daily life has not direct aftermaths on subjects.

"It states that, since the dangers posed by global warming aren't tangible, immediate or visible in the course of day-to-day life, many will sit on their hands and do nothing of a concrete nature about them. Yet waiting until such dangers become visible and acute - in the shape of catastrophes that are irrefutably the result of climate change- before being stirred to serious action will be too late" (Giddens, 2011, p. 2).

Giddens illustrates brilliantly how the roots of global warming is not necessarily intertwined to the effects of carbon but to the dependency of industrialized nations from oil. Afterward the war between Arab league and Israel in 70s, the developed countries experienced a new situation in the ways of producing. This event led certainly to European and Latin-American countries to make up different strategies to replace the oil with other forms of energies. US, rather, was obliged to intervene Middle East, first and foremost Saudi Arabia in quest of coal, oil and gas. The American interest in Middle East not only engendered some long-simmering conflicts but also serious problems in their reserves. What is most important in this case, does not seem to be the effects of global warming, which Giddens accepts, are in controversy but the social problems the war for resources, the oil creates.

\section{GREen TOURISM THROUGH THE LENS OF LATIN AMERICANS}

Over years, Latin American scholars debated among two interesting but not for that less problematic tendencies in tourism fields: European thinking with strong focus the Mediterranean destinations situated through Spain and Portugal and Anglo-Saxon tradition which envisages tourism as an mechanism of alienation. Additionally, though the classic studies not only were oriented to the fallouts of tourism in territory but echoed Jafari's concern, expressed in his manuscript Research and Scholarship (originally published in 1990) on the possibility tourism places environment in jeopardy (Acerenza 1985; Boullon 2006). For this "cautionary platform" (borrowing Jafari`s terms), unless tourism is duly regulated, local towns experience a faster decline of attractiveness. This raises a more than pungent question, What would be the instrument to prevent this apocalyptic setting?.

The introduction of rationality adjoined to the formation of next practitioners results in the orchestration of planning programs to find and correct those glitches produced by the induction of mass-tourism. Jointly to Miguel Angel Acerenza and other colleagues, Boullon made the first step in creating a new conceptual platform where academicians discussed further on the toolkits to prevent the negative aftermaths of tourism in territory. CICATUR (Centro Latinoamericano de Capacitacion Turistica) was an innovative conceptual project aimed at educating new professionals in tourism and hospitality even establishing a new methodology to be emulated by potential fieldworkers. Although the threshold of time covered CICATUR in the dust of oblivion for young students, it is very interesting to see how their mainstream values persisted. One of the main aspects that defined this organization was the needs of expanding the current understanding of tourism its effects on daily life of people as well as the needs for states to intervene to solve those troubles created by tourism in the territory, and of course in doing so, planning would be an important instrument to forecast "public policies" in a not so distant future. Basically, CICATUR not only shed the light on the intersection of tourism with ecology, but also illuminated many emergent voices which today pivot in tourism research. Doubtless, one of them is Regina Schluter, who calls the attention that in Latin America, tourism resulted from the needs of protecting environment. Though years later, scholars coined the name of green tourism to explain some eco-friendly activities no less true was that the needs of 
preservation which crystalized the rise of national parks was a sufficient reason to stimulate tourism (Schluter, 2003; 2006; 2008).

As the previous argument given, Miguel Gonzalez Herrera, lecturer at Universidad Central de las Villas, Cuba holds the thesis that the meaning of control is vital to organize the geography where tourism operates. Without a correct diagnosis and clarification of those factors which produces negative environmental impacts, tourism backfires.

From a Marxian perspective, Cordero Ullate (2006) argues convincingly that tourism far from bringing poverty relief to local communities, paves the pathways for a new process of accumulation where the concept of nature and beautiness determine what landscapes may be commoditized or not. Starting from the premise any society is a projection how leisure is formed, Cordero Ullate acknowledges that capitalism is based on the axis of accumulation which is legally legitimized by tourist consumption. While tourism allows a revitalization of natural resources, the material asymmetries between classes are never broken. This happens not only because tourism research failed to shift its original epistemology which focus on profit-oriented programs as the only realities that can be measured, but also by the misunderstanding on capitalism as the key factor that threatens environment. In this respect, some works highlight the needs of defining eco-tourism as something else than the respect for nature. Westernized culture needs, for this paradigm, the acceptance of a new climate of governance to place asunder from the alienation of urban-dwellers. In this context, rural or green tourism offers a good opportunity to achieve a global ecological governance in the world (Duffy 2006; Laws, 2011; Fennell \& Dowling, 2003; Fennell 2014). Douglas Molina Orjuela (2013) contends that rural tourism and global governance are inevitably entwined. Per his viewpoint, local communities are in quest of adopting tourism not only to alleviate their poverty but for enhancing policies for the protection of environment. In this mayhem, he recognizes that what Latin American uses as ecological practices not necessarily are shared by Europeans and vice versa. To put this in other terms, some tensions between concepts should be reconsidered under the frame of globalization which melts peoples into cultures. Despite the concept of rurality was widely discussed in the specialized literature, rural tourism shows an alternative path that combines the liberality of market with ecology. One cannot prosper without the other and vice versa. This seems to be the reason why green-tourism is conducive to a sustainable exploitation of resources, which if regulated, can bring various benefit to local stakeholders. He reviews extensively the study cases of Europe to contrast it to the experience in Latin America. Green tourism through Spain has adopted patterns which can be distinguished from other European countries as France or England. The success of rural tourism in Spain is accompanied by the international investment which looked the opportunity of profits. Rather, France evinces a contrasting example since poverty and devastation post WWII context were the two main goals policy makers followed to adopt the ecological paradigm. This trend was reconfirmed by the emergence of land management through 70s decade. From 1963 on, government disposed the creation of National Park (Missions Interministerielles) while green ecological destinations were created to be complement to farmers` interests. What would be more than interesting to discuss is to what extent, Latin America goes in a contradictory and non-linear direction. Orjuela adds, though Latin America never reached a sustainable and unified policy for green tourism (from Mexico to Argentina) there are interesting points of convergence which start from the needs of farmer as well as rural dwellers to revitalize their production through tourist consumption.

The case of Brazil deserves attention since many of studies on tourism and its impacts in Amazonas are not published by Brazilians but by English speaking scholars. To set an example, Wallace \& Pierce (1996) studied "ecotour lodges" in Amazonia by means of questionnaire administration to visitors, front desk staff and tourists. This investigation centers on a gap between ideals in ecoconsumers which can be expressed by what demands want, and the principle of ecology, represented by what Amazonia offers. In spite of tourists are in quest of nature and of course they wish consuming "authenticity", they contribute less than expected to educate local people. In other research with epicentre in Australia, Ryan, Hugues \& Chirgwin (2000) explain that self defined eco-tourists gain a cognitive instead of affective experience. Centred on the needs of gazing the others, the roots of this experience comes from the culture of Ocular-centrism which is associated to "the spectacle" rather than an attempt to learn from others. As stated, tourism depends not only on its complexity but the lens where we evaluate its effects on community. If a profit-oriented paradigm is prioritized over other values, green-tourism exhibits a fertile ground for the expansion and enhancement of communities, while for some fieldworkers it poses a serious alarm since the possibilities sustainable 
tourism far for solving local troubles, were functional to "the commoditization of cultures" (MacCannell 1992; de Aceredo Grunewald, 2002; Korstanje 2012).

Daniel Hiernaux (2002) confirms the success of tourism depends not only on how social imaginary adopts some allegories that precedes tourist-consciousness as leisure, consumption and liberal trade, but also how the sense of happiness is visually exploited. He acknowledges that, after all, tourism rests on four main discourses as

a) The quest for eternal happiness

b) The needs of escapement

c) The discovery of Otherness.

d) The return to lost virgin paradise, which means the needs to come back to natural environment.

It would be interesting to discuss the needs of recovering lost-paradise, a point which is present in an extensive background of Christian Mythology, as an impossible attempt to recover the mother womb. For interested scholars to develop the intersection of nature and paradise, see Korstanje (2010), Korstanje \& Busby (2010) and Cardona, Criado \& Cantallops (2015), and finally Cantallops \& Cardona (2015). At a closer look, the original sin distanced humankind from its nature, but by means of tourism, the descendants of Adam emulate daily the needs of recovering Eden. In this token, tourism should be seen as a rite of passage which validates the main cultural values of society.

As the previous argument given, Nogues Pedregal described how tourism should be defined as a vital force that threatens not only daily life of local communities but also their traditional means of subsistence. Often, for those cultures which historically lived from agriculture or fishing tourism situates paradoxically as a great enemy or ally, depending their flexibilities to change the means of production and axis of accumulation (Nogues Pedregal 2015).

Last but not least, the barriers of language impede many English speaking natives to understand the evolution of Eco Tourism in Latin-America. This represents a serious problem to forge an interdisciplinary research since English native speakers are not interested in reading other manuscripts than published in English. Even, this leads to partial diagnosis or one-sided vision of Ecology in South America. The reason why this occurs seems to be easier than thought. The well-read scholars only allude to Latin America tangentially or touching themes they misunderstand. Secondly, it is interesting not to lose the sight that North-South dependency balks a frank dialogue which may be helpful to exchange experiences. Though Latin America has been pioneer in the study of ecosustainable tourist destination, after the inauguration of CICATUR less is known for Anglo-world. At the time, the conceptual paradigms are created in England and US only to be validated in the global south as Argentina, Mexico, or Brazil, by producing an academic exchange which rests on shaky foundations. In this vein, this essay-review synthesizes one of the main worries in green tourism in order to transcend the borders of language and culture.

\section{Conclusion}

In this review-essay we have brought the problem of sustainability to the foreground stressing on how Latin Americans adopted their own paradigms on this issue. The precedents of CICATUR not only shed light on the needs for protecting natural environment but also paved the ways for the rise of an ecological consciousness. Although the study cases of Spain and its Mediterranean coast has exerted a great influence over Latin American scholars, no less true was that green tourism faced a great fragmentation which often is linked to derivative meaning as rural tourism, sustainable tourism and even eco-friendly tourism. Basically, green tourism will offer in the years to come a great opportunity to re-consider the paradigm of sustainability. One of the dangers eco-tourism will face, doubles, seems to be the dependency between central and peripheral economies. While green tourism destination needs from sustainability to survive, central economies are doing nothing to alter their practices that daily contaminate the planet. The successive failures to agree coordinated policies to reduce the carbon gases not only validates the idea that global capitalism rests on material asymmetries which are very hard to shift, but we have to overcome the obstacles posed by the theory of development in poor nations. 


\section{REFERENCES}

Acerenza, M. A. (1985). Planificación estratégica del turismo: esquema metodológico. Estudios turísticos, (85), 47-70.

Ashworth, G. J. (1992). Planning for sustainable tourism. Town Planning Review, 63(3), 325.

Bandyopadhyay, R. (2012). "To be an Englishman for a Day": marketing colonial nostalgia in India. Annals of Tourism Research, 39(2), 1245-1248.

Boullón, R. (2006). Espacio turístico y desarrollo sustentable. Aportes y transferencias, 10(2), 17-24.

Bramwell, B., \& Lane, B. (1993). Sustainable tourism: An evolving global approach. Journal of Sustainable Tourism, 1(1), 1-5.

Cantallops, A. S., \& Cardona, J. R. (2015). Holiday destinations: The myth of the lost paradise?. Annals of Tourism Research, 55, 171-173.

Cardona, J. R., Criado, M. D. C. A., \& Cantallops, A. S. (2015). El mito del paraíso perdido en la definición del destino turístico. Estudios y perspectivas en turismo, 24(3), 715-735.

Cole, S. (2006). Information and empowerment: The keys to achieving sustainable tourism. Journal of sustainable tourism, 14(6), 629-644.

Comaroff, J. L., \& Comaroff, J. (2009). Ethnicity, Inc. University of Chicago Press.

Cordero Ullate, A. (2006) Nuevos Ejes de acumulacion y naturaleza: el caso del turismo. Buenos Aires, Clacso

de Azeredo Grünewald, R. (2002). Tourism and cultural revival. Annals of Tourism Research, 29(4), 1004-1021.

Duffy, R. (2006). Global environmental governance and the politics of ecotourism in Madagascar. Journal of Ecotourism, 5(1-2), 128-144.

Esteva, G., \& Prakash, M. S. (1998). Beyond development, what?.Development in Practice, 8(3), 280-296.

Fennell, D. A., \& Dowling, R. K. (Eds.). (2003). Ecotourism policy and planning. Wallingford, CABI.

Fennell, D. A. (2014). Ecotourism. Abingdon, Routledge.

Font, X., \& Tribe, J. (2001). Promoting green tourism: The future of environmental awards. The International Journal of Tourism Research, 3(1), 9.

Gibson, A., Dodds, R., Joppe, M., \& Jamieson, B. (2003). Ecotourism in the city? Toronto's green tourism association. International journal of contemporary hospitality management, 15(6), 324327.

Giddens, A. (2009). The politics of climate change. Polity Press, Cambridge, UK.

Gonzales Herrera, M (2004) "Gestion Ambiental para un modelo Sostenible". Estudios y Perspectivas en Turismo, 13 (1-2): 35-49

Hall, C. M. (1991). Introduction to tourism in Australia: impacts, planning and development. Longman Cheshire.

Harrison, D. (1996). Sustainability and tourism: Reflections from a muddy pool. Sustainable tourism in islands and small states: Issues and policies, 69-89.

Hiernaux, D (2002) “Turismo e Imaginarios". En Imaginarios Sociales y turismo Sostenible. Hiernaux D N, Cordero A, \& Duynen Montijn L (eds) San Jose, FLACSO, 7-35

Ingold, T. (2000) The Perception of environment. London, Routledge.

Ingold T (2011) Being Alive, essays on movement, knowledge and description. London, Routledge.

Kadt, E. D. (1979). Tourism. Passport to development? Perspectives on the social and cultural effects of tourism in developing countries. Oxford, Oxford University Press.

Krippendorf, J. (1982). Towards new tourism policies: The importance of environmental and sociocultural factors. Tourism Management, 3(3), 135-148.

Krippendorf, J. (1986). The new tourist-turning point for leisure and travel. Tourism Management, $7(2), 131-135$.

Krippendorf, J. (1987a). Ecological approach to tourism marketing. Tourism Management, 8(2), 174176.

Krippendorf, J. (1987b). The Holiday-makers: Understanding the Impact of Travel and Tourism. Oxford: Butterworth-Heinemann. 
Korstanje, M. (2010). La Isla y El Viaje Turístico-Una Interpretación del Filme de Michael Bay, Desde El Psicoanálisis y El Pensamiento Filosófico Moderno y Contemporáneo (The Island and the Journey Tour-An Interpretation of Film Michael Bay, from Psychoanalysis and Philosophical Thought Modern and Contemporary)(in Spanish). Anuario Turismo $y$ Sociedad, 11, 155-174.

Korstanje, M. (2012). Reconsidering cultural tourism: an anthropologist's perspective. Journal of Heritage Tourism, 7(2), 179-184.

Korstanje, M., \& Busby, G. (2010). Understanding the Bible as the roots of physical displacement: the origin of tourism. E-Review of Tourism Research,8(3), 95-111.

Korstanje, M. E., \& George, B. (2012). "Global warming and tourism: chronicles of apocalypse?". Worldwide Hospitality and Tourism Themes, 4(4), 332-355.

Korstanje, M. E., \& George, B. (2015). The Imposible Sustainability: Applications Of Relational Perspective In Tourism Fields. Ecoforum Journal,4(1), 2.

Hall, D. (2004). Rural tourism development in southeastern Europe: Transition and the search for sustainability. International Journal of Tourism Research,6(3), 165-176.

Hjalager, A. M. (2000). Consumerism and sustainable tourism. Journal of Travel \& tourism marketing, 8(3), 1-20.

Jafari, J. (1990). Research and scholarship: the basis of tourism education. Journal of tourism studies, 1(1), 33-41.

Jafari, J. (2005). Bridging out, nesting affield: powering a new platform.[Opinion piece.]. Journal of Tourism Studies, 16(2), 1.

Jones, A. (1987). Green tourism. Tourism management, 8(4), 354-356.

Lash, S., \& Urry, J. (1993). Economies of signs and space (Vol. 26). London, Sage.

Laws, E. (2011). Tourist destination governance: Practice, theory and issues. Welingford, Cabi.

MacCannell, D. (1992). Empty meeting grounds: The tourist papers. London, Routledge.

McBoyle, G. (1996). Green tourism and Scottish distilleries. Tourism Management, 17(4), 255-263.

McMichael, P. (2016). Development and social change: A global perspective. London, Sage Publications.

Nogues Pedregal, A M (2015) Etnografia de Un Espacio Turístico. El Sauze, PASOS Produce.

Orjuela, D. E. M. (2013). Turismo rural y gobernanza ambiental: conceptos divergentes en países desarrollados y países en vías de desarrollo. Turismo y Sociedad, 14, 215-235.

Roberts, L., \& Hall, D. (Eds.). (2001). Rural tourism and recreation: Principles to practice. Wallingford, CABI.

Romeril, M. (1989). Tourism and the environment—accord or discord?. Tourism management, 10(3), 204-208.

Ryan, C., Hughes, K., \& Chirgwin, S. (2000). The gaze, spectacle and ecotourism. Annals of Tourism Research, 27(1), 148-163.

Saarinen, J. (2006). Traditions of sustainability in tourism studies. Annals of tourism research, 33(4), 1121-1140.

Schlüter, R. G. (2003). El turismo en Argentina: Del balneario al campo. Buenos Aires, CIET

Schluter, R. (2006). Turismo y patrimonio gastronómico. Una perspectiva. Buenos Aires: CIET.

Schluter, R. (2008). Turismo: una versión integradora. Buenos Aires, CIET.

Scott, D., Hall, C. M., \& Stefan, G. (2012). Tourism and climate change: Impacts, adaptation and mitigation. Abingdon, Routledge.

Stabler, M. J., \& Goodall, B. (1997). Environmental awareness, action and performance in the Guernsey hospitality sector. Tourism Management, 18(1), 19-33.

Sofield, T. H. (2003). Empowerment for sustainable tourism development (Vol. 7). Oxford, Emerald Group Publishing.

Timothy, D. J., Sharpley, R., \& Telfer, D. J. (2002). Tourism and community development issues. Tourism and development: Concepts and issues, 149-164.

Wallace, G. N., \& Pierce, S. M. (1996). An evaluation of ecotourism in Amazonas, Brazil. Annals of Tourism Research, 23(4), 843-873.

Wheeller, B. (1991). Tourism's troubled times: Responsible tourism is not the answer. Tourism Management, 12(2), 91-96. 